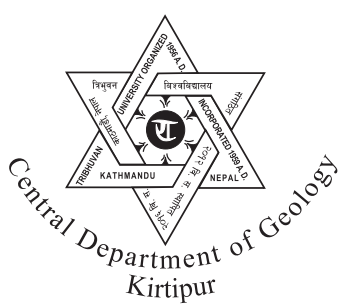

\title{
Petrology of Rapti River sand, Hetauda-Chitwan Dun Basin, Central Nepal; an example of recycled provenance
}

\author{
*Naresh Kazi Tamrakar ${ }^{1}$, Surendra Maharjan ${ }^{1}$ and Madhusudan Bhakta Shrestha ${ }^{2}$ \\ ${ }^{1}$ Central Department of Geology, Tribhuvan University, Kirtipur, Kathmandu, Nepal \\ ${ }^{2}$ Department of Forestry, Shinshu University, Nagano, Japan
}

\begin{abstract}
The Rapti River in the Central Nepal drains fold-thrust belts of the Lesser and the Sub-Himalayas as demarcated by four major thrusts, and is located in humid sub-tropical climatic zone. Within the Sub-Himalaya (Siwalik Group), a wide Dun Valley gives way the long low-gradient Rapti River in the northeast region, therefore, forming a characteristic piggy-back basin within the foldthrust belts. Sands from the Rapti River were obtained and analysed to characterise composition and texture, to verify its provenance, and to compare with modern and ancient sands/sandstones from different basins having similar tectonic setting. The Rapti River sand is quarto-lithic in composition. It plots on recycled orogeny provenance field in the QFL and QmFLt triangle diagrams showing no major difference in provenance with other sands/ sandstones from different climates. However, the Rapti River sand is remarkably poorer in feldspar but richer in lithic fragments and quartz compared to the other sands/sandstones.
\end{abstract}

\section{INTRODUCTION}

The provenance of sediments includes all aspects of source area including source rocks, climate, relief and hydrodynamics of environment (Pettijohn 1984; Johnsson 1993). Some workers believe in tectonic setting as a major controlling factor (Ingersoll and Suczek 1979; Dickinson et al. 1986; Johnsson 1990), while others in relief (Hayes 1962; Mann and Cavoloc 1973), climate (Breyer and Bart 1978) mixing (Cavazza et al. 1993) and reworking (Cox and Lowe 1995). Johnsson (1990) concluded that basic differences in tectonic setting are not erased even by intense tropical weathering operating for long time. Arribas et al. (2000) concluded that mixing is more important than abrasion in changing sand composition during transport. Cox and Lowe (1995) suggested recycling to be an important process in affecting sand composition.

*Corresponding author:

E-mail address: ntamrakar@hotmail.com
Although several variables tend to affect composition of sand and sandstone, these variables are in fact largely influenced by tectonic settings of sedimentary environments (Johnsson 1990). This paper therefore characterises composition and texture of modern sand as one of the examples from environment of known climate, relief, source rock and tectonic setting.

\section{HETAUDA-CHITWAN DUN BASIN}

\section{Topography, drainage and climate}

The Hetauda-Chitwan Dun Basin (HCDB) covers 3374 sq. km, and comprises the Lesser Himalaya (elevation $2347 \mathrm{~m}$ a.m.s.l.) in the north, and the SubHimalaya both in the north (1000 $\mathrm{m}$ a.m.s.l.) and the south (800 m a.m.s.l.) of the basin (Fig. 1). The Dun valley is oriented $\mathrm{E}-\mathrm{W}$, with a very gentle regional westward slope.

The Rapti River stretches for $118 \mathrm{~km}$ from 


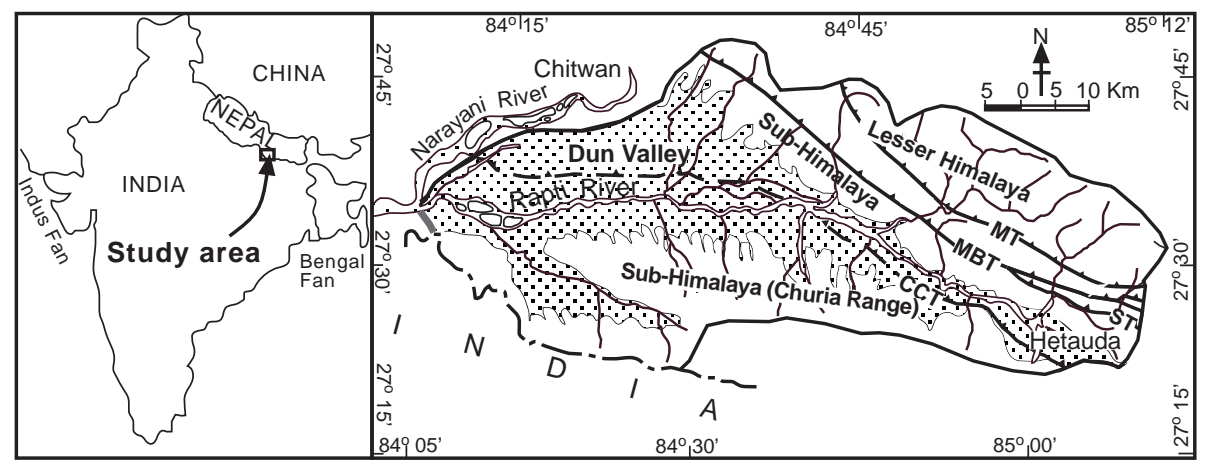

Fig. 1 Location map of the study area; $\mathrm{MT}=$ Mahabharat Thrust, MBT = Main Boundary Thrust, ST $=$ Samari Thrust, and $\mathrm{CCT}=$ Central Churia Thrust

headwaters to the outlet at an average slope of 0.036 $\mathrm{m} / \mathrm{m}$ in headwaters in the north and $0.0002 \mathrm{~m} / \mathrm{m}$ between the emergence in the Sub-Himalaya and the outlet point in the west (Fig. 2). The Rapti River and some major tributaries incise the Mahabharat and the Sub-Himalayas. After emerging into the Dun Valley, the Rapti River meanders with frequent braiding in the middle stretch. The river largely carries gravel and sand.

The HCDB has a humid subtropical climate, with a wet period between June and September and a dry period between November and April. Annual rainfall in headwaters is 1500-2000 mm (DHM 1998), whilst that in the valley (Hetauda Station) is 1847-3323 $\mathrm{mm}$. The maximum and minimum annual air temperatures are $29.3^{\circ} \mathrm{C}$ and $16.8^{\circ} \mathrm{C}$, respectively. The maximum and minimum relative humidity at local times 8:45 and 17:45 are $81 \%$ and $71 \%$, and $78 \%$ and $67 \%$, respectively. The average annual peak discharge of the Rapti River calculated from the records of DHM (1998) from the Rajaiya Station, at about $1 \mathrm{~km}$ downstream from the sampling point

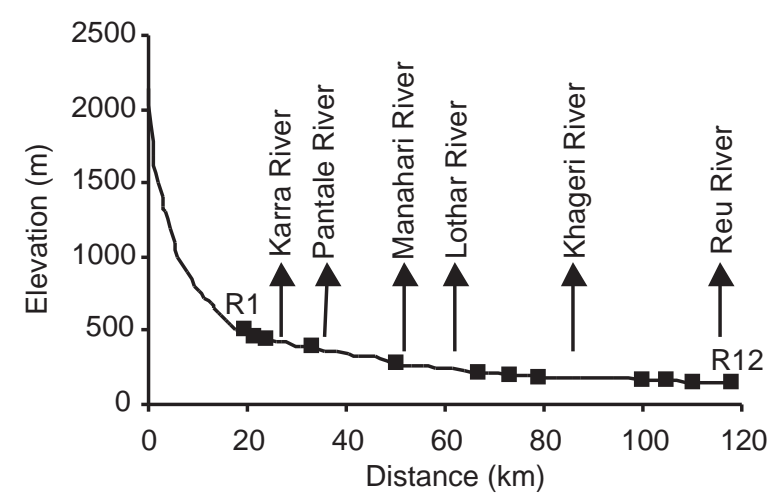

Fig. 2 A profile of the Rapti River and location of sample points
R4 (Fig. 3), is $525 \mathrm{~m}^{3} \mathrm{~s}^{-1}$. The maximum monthly discharge ranges from 18.5 to $684 \mathrm{~m}^{3} \mathrm{~s}^{-1}$, and high flows occur in June-September.

\section{Geological setting}

The HCDB constitutes partly the Lesser and the Sub-Himalayan fold-thrust belts. The foreland sedimentation prevailed in Neogene after the collision tectonics and then the Sub-Himalayas (Siwaliks) came into existence due to folding and thrusting. Four major thrusts the Mahabharat Thrust, the Samari Thrust, the Main Boundary Thrust and the Central Churia Thrust that extend NW-SE and dip north demarcate five tectono-geomorphic zones from the north to the south (Fig. 3). These zones are (1) the Bhimphedi Group (Stöcklin and Bhattarai 1982); high-grade metamorphic rocks (schist, gneiss and amphibolite), granite and pegmatite, (2) the Upper Nawakot Group (low-grade metasedimentary and sedimentary rocks; slates, phyllite, chloritic phyllite, quartzite, limestone and dolostone), (3) the PreSiwalik Group? (Tamrakar et al. 2002; quartzose sandstone, shale, siltstone and conglomerate), (4) northern belt of the Siwalk Group and (5) southern belt of the Siwalik Group (sandstone, siltstone, mudstone and conglomerate) from the north to the south. Between the northern and the southern belts of the Siwalik Group, a wide Dun Valley extends E-W.

The Dun Valley constitutes five distinct geomorphic surfaces. According to Kimura (1994) the Higher and the Upper surfaces formed as alluvial fans in the foot of the Mahabharat and the SubHimalayas during middle Pleistocene (Pre-Dun Phase). The Middle Terraces resulted after upheaval of the hanging walls of the Main Frontal Thrust and the Central Churia Thrust probably during late 


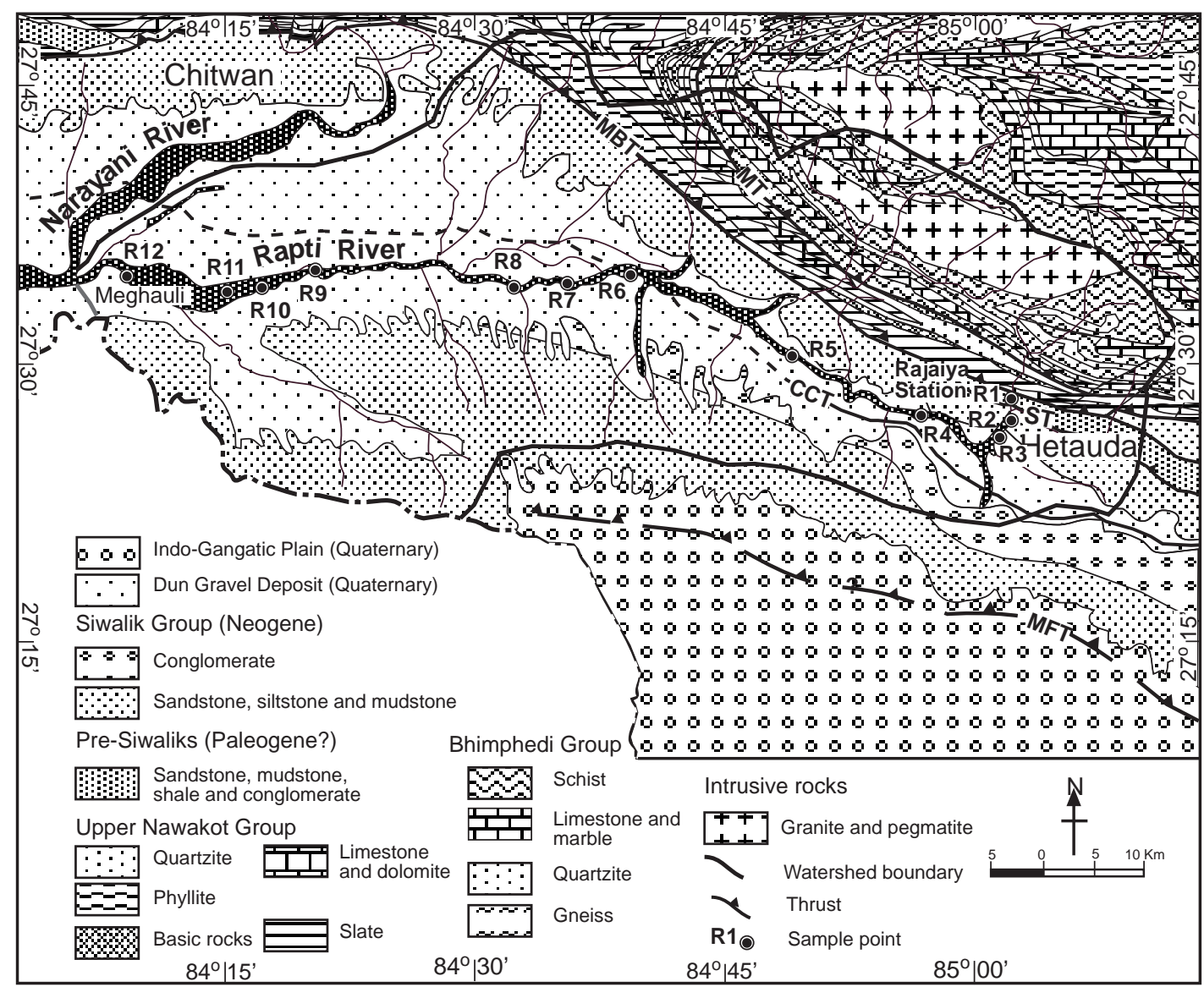

Fig. 3 Geology of the Rapti River area and sampling sites (compiled after Stocklin and Bhattarai 1982; DMG 1984; Tamrakar 2004)

Pleistocene, and sedimentation from Siwalik rocks and earlier terrace deposits from the south to north flowing tributaries. The Lower Terraces formed after crustal deformation, indicate fluvial, swamp and lakes sedimentation (Kimura 1994). Terrace deposits of the Dun Valley are composed of gravel, sand and mud, and are distributed in the central part of the HCDB.

\section{METHODOLOGY}

A bulk of $500 \mathrm{~g}$ of sand (matrix) associated with gravel in side bar or mid bar of the Rapti River was sampled from each sampling site between Hetauda and Meghauli (Fig. 1) for mineralogical and textural analyses. Each sample was sieved at the interval of 1 . One hundred quartz grains from medium sand grade were estimated for roundness ( ) and maximum projection sphericity ( $p$ ) using comparators. Each of the bulk samples was cemented using epoxy, thin- sectioned and stained for carbonates with potasium ferricyanide and alizarin red, and also stained for potash feldspar grains with sodium cobaltinitrite. Three hundred grains per thin section were pointcounted for modal analyses using Gazzi-Dickinson's method of counting.

\section{RESULTS}

\section{Texture of sand}

The samples are very coarse to fine sand, the majority being very coarse sands (Table 1 ) considering their median size grades. Quartz grains exhibit medium range of $p(0.75-0.79)$ and are subangular to subrounded ( $=1.65-3.24$ ). Distribution patterns of roundness in R1 to R5 are similar (Fig. 4). Similarly, the patterns in R6 to R12 are similar, but a remarkable decrease in angular fragments at the expense of subrounded and rounded grains can be seen. $\mathrm{p}$ and of quartz tend to enhance with downstream distance. 


\section{Composition}

\section{Quartz}

Quartz is the dominant component of the sand (Table 2). Monocrystalline quartz $(\mathrm{Qm})$ ranging from 27 to $54 \%$ exceeds polycrystalline quartz $(\mathrm{Qp})$ $(15-41 \%)$ in every sample. Undulose Qm grains dominate nonundulose Qm grains showing their derivation probably from finely to coarsely crystalline metamorphic rocks such as quartzite, phyllite and schist. The nonundulose Qm grains were perhaps derived from the quartz vein, quarzite, sandstone and siltstone. Qp grains are mostly foliated and were probably derived from the high-grade metamorphic rocks such as schist and gneiss. Polycrystalline equigranular quartz probably came from granite, pegmatite and quartzite. The total quartz (Q) becomes abundant in the downstream segments of the Rapti River, and it shows significant positive correlation with river distance (Fig. 5a) suggesting increase in maturity of sand.

\section{Feldspar}

Feldspars (F) represent low amount in sand (between 1 and 4\%) and are orthoclase, microcline and twinned plagioclase. The feldspars were probably derived from granitic rocks and metamorphic rocks of the Lesser Himalayas. The huge source rocks of feldspars are distributed in the Lesser Himalaya in the northern region of the HCDB. The amount of feldspar becomes very low in the samples as the river emerges from the Sub-Himalaya in to the Dun Valley, most probably due to dilution of feldspar by weathering and breakdown within the upstream stretch. Hayes (1962) also came into the similar
Table 1: Grain size of sand and shape of quartz grains of sand from the Rapti Rivers

\begin{tabular}{|c|c|c|c|c|c|c|}
\hline \multicolumn{5}{|c|}{ SampleDistanceMedian sizeRoundness, } & \multicolumn{2}{|c|}{ Sphericity, $\mathrm{p}$} \\
\hline & $\mathrm{km}$ & & Mean & STDEI & MEA & STDEV \\
\hline$\overline{\mathrm{R} 1}$ & 19.4 & -0.3 (VCS) & 1.65 & 0.67 & 0.75 & 0.07 \\
\hline $\mathrm{R} 2$ & 21.7 & 0.7 (CS) & 2.27 & 1.06 & 0.77 & 0.06 \\
\hline 23 & 0 & ) & 1. & 0.92 & 0. & 0.07 \\
\hline $\mathrm{R} 4$ & .2 & -0.4 & 1.9 & & 6 & 0.06 \\
\hline R5 & 50.3 & -0.6 & 1.92 & 0.96 & 0.78 & 0.06 \\
\hline 6 & 66.7 & -0.6 & 2.8 & 1.02 & 0 . & 0.06 \\
\hline R7 & 3.2 & -0.6 & 3.2 & 0. & 0. & 0.06 \\
\hline R8 & 78.8 & -0.4 & 3.07 & 0.98 & 0.78 & 0.06 \\
\hline R9 & 99.8 & 2.1 (FS) & 2.88 & 0.93 & 0.78 & 0.06 \\
\hline R10 & 105.0 & $0.5(\mathrm{CS})$ & 2.80 & 0.97 & 0.77 & 0.06 \\
\hline R11 & 10.3 & 0.2 & 3.0 & 0.88 & 0.79 & 0.07 \\
\hline $\mathrm{R} 12$ & 118.3 & 1.8 (MS) & 2.83 & 1.06 & 0.79 & 0.07 \\
\hline
\end{tabular}

FS = fine sand; MS = medium sand; CS = coarse sand;

$\mathrm{VCS}=$ very coarse sand $; \mathrm{STDEV}=$ Standard deviation

conclusion that feldspars are rapidly destroyed in high-gradient streams of mountain rivers. Once the proportion of feldspars has been diluted, no further variation of feldspar occurs along the low-gradient stretch of the Rapti River.

\section{Lithic fragments}

Sedimentary lithic fragments (Ls) that range from 6 to $35 \%$ are composed of siltstone, sandstone, shale and carbonate lithics (Lc). Most of the Ls, except some of the Lc, are derived from the Siwalik Group. Carbonate lithics are substantial in R1 and R2 from the upstream portion of the river and they were probably derived from the Upper Nawakot Group.

Metamorphic lithics (Lm) range from 1 to $24 \%$ and are represented by schist followed by phyllite, argillite and amphibolite in decreasing abundance. The metamorphic lithics were probably derived from (a)

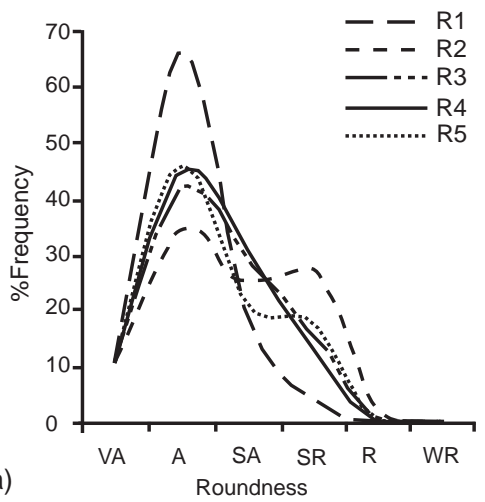

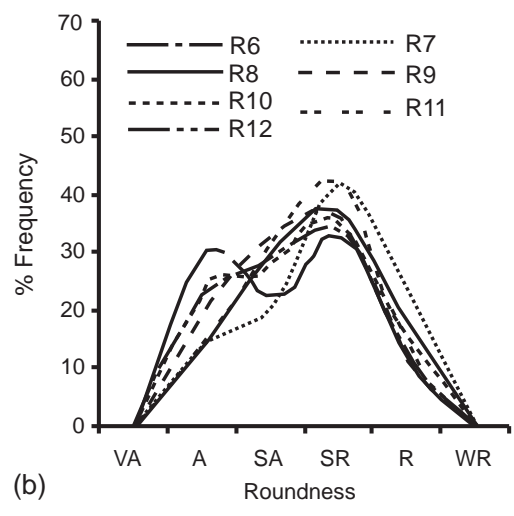

Fig. 4 Percent frequency of roundness categories for quartz of sand samples (VA = very angular, $\mathrm{A}=$ angular, $\mathrm{SA}=$ subangular, $\mathrm{SR}=$ subrounded, $\mathrm{R}=$ rounded and $\mathrm{WR}=$ well rounded) 


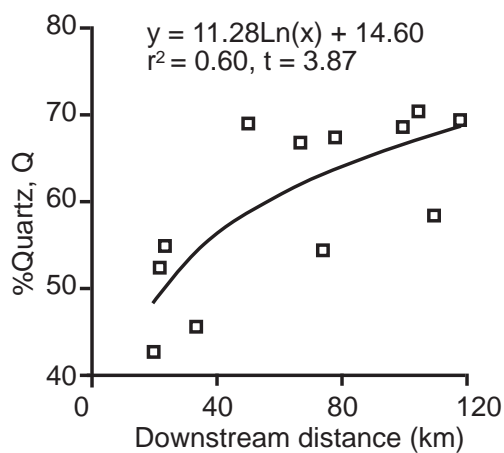

(a)

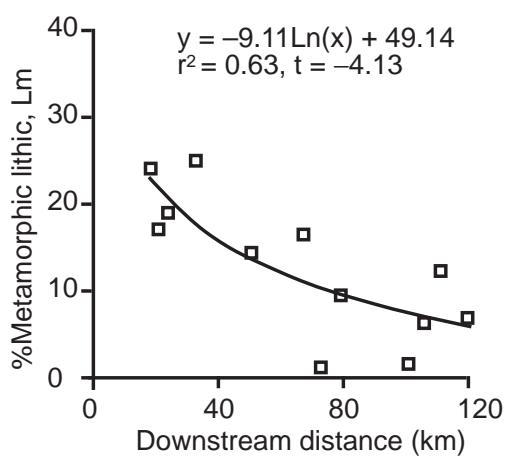

(b)

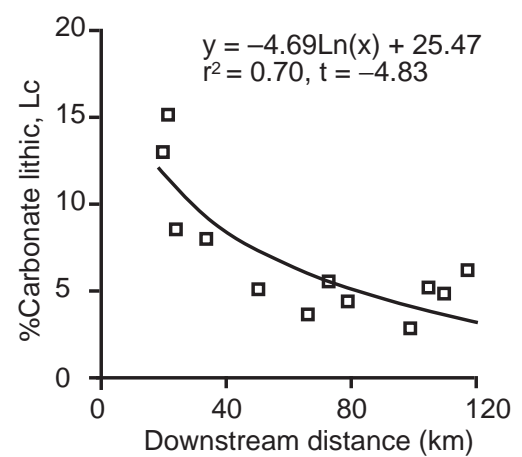

(c)

Fig. 5 Downstream trends of (a) Quartz, (b) Metamorphic lithics and (c) Carbonate lithics

the Lesser Himalayas. The total metamorphic lithics (Lm) and carbonate lithics (Lc) show significant negative correlation with downstream distance (Fig. $5 \mathrm{~b}$ and $5 \mathrm{c})$.

\section{Modal sand composition and provenance}

The overall QFL composition of the Rapti River sand is $\mathrm{Q}_{66}, \mathrm{~F}_{2}$ and $\mathrm{L}_{32}$ (Table 2). The samples are quartzo-lithic sand in which percent quartz exceeds percent lithic fragments (Fig. 6a). The proportion of lithic fragments diminishes from the downstream sites. The QmFLt composition is $\mathrm{Qm}_{39} \mathrm{~F}_{2} \mathrm{Lt}_{59}$ and the plot (Fig. 6b) shows more Lt compared to Qm.

The sand samples plot on recycled orogeny field of the QFL diagram (Fig. 7a), and transitional recycled field of the QmFLt diagram (Fig. 7b). In agreement with the present-day environmental setting where collision tectonics and subsequence folding and thrusting provide enormous sediments to the rivers, the plots of the recent river samples indicate a recycled provenance field.

Comparing to the modern sands of the Manahara-Bagmati River from the humid temperate region (Kathmandu Basin) and to the remnant-ocean sands from the Bengal and Indus Fans (Fig. 7a), the Rapti River sands are poorer in feldspar but are richer in quartz. This could be because of greater degree of sub-tropical weathering and/or mixing of reworked sands from the temporary storage of the Dun Valley sediments. The remnant-ocean sands (Tertiary) from the Bengal and Indus Fans are richer in feldspar compared to the modern river sands from the Rapti and Manahara-Bagmati Rivers, as caused by volcanic and plutonic activities (Ingersoll and Suczek 1979;
Suczek and Ingersoll 1985). The Rapti River sands are poorer in feldspar and richer in lithic fragments compared to the foreland sandstones of the Siwalik Group of Neogene Period (Fig. 7a).

Comparing the data of the headwaters of the Rapti River (X1 and X2; Fig. 7b) after DeCelles et al. (1998) with the data of the present study (in which samples were from the low-gradient stretches) a distinct compositional shift has been obtained. The $\mathrm{X} 1$ sand from the most upstream portion is richer in feldspar probably due to proximity of granitic and high-grade metamorphic rocks in the region, therefore it plots on a mixed provenance field. Further downstream, where low-grade metamorphic and sedimentary rocks prevail, the X2 sand shows compositional shift from a mixed to a transitional recycled field. In the low-gradient stretches, feldspars are almost underrepresented possibly due to weathering and destruction of this component or due to excessive input of reworked quartz and lithic fragments along the river course from the earlier storage. Therefore, the compositional shift occurs with diminished feldspars more towards the transitional recycled provenance field (Fig. 7b).

\section{CONCLUSIONS}

1. Quartz grains, which are angular to subangular, monocrystalline to polycrystalline, undulose to nonundulose were derived from crystalline and highgrade metamorphic rocks. The tendency of increase in quartz roundness in the downstream stretches of the Rapti River suggests incorporation of recycled quartz, which were probably derived from sandstones (Siwalik Group) and the Dun Gravel Deposits. 
Table 2: Modal composition the Rapti River sand

\begin{tabular}{|c|c|c|c|c|c|c|c|c|c|c|c|c|c|}
\hline \multirow[b]{2}{*}{$\%$ Grains } & & \multicolumn{12}{|c|}{ Samples } \\
\hline & & $\mathrm{R} 1$ & R2 & R3 & $\mathrm{R} 4$ & R5 & R6 & R7 & R8 & R9 & $\mathrm{R} 10$ & R11 & $\mathrm{R} 12$ \\
\hline \multicolumn{14}{|l|}{ Monocrystalline quartz (Qm) } \\
\hline Qm: undulose & Qmu & 21 & 22 & 25 & 17 & 37 & 21 & 25 & 29 & 21 & 24 & 20 & 33 \\
\hline Qm: nonundulose & Qmnu & 7 & 8 & 10 & 7 & 17 & 7 & 10 & 11 & 7 & 11 & 10 & 21 \\
\hline Total monocrystalline quartz & $\mathrm{Qm}$ & 28 & 30 & 35 & 24 & 54 & 28 & 35 & 40 & 27 & 36 & 30 & 54 \\
\hline \multicolumn{14}{|l|}{ Polycrystalline quartz (Qp) } \\
\hline Qp: equigranular & Qpe & 9 & 17 & 5 & 8 & 5 & 10 & 12 & 9 & 6 & 9 & 16 & 7 \\
\hline Qp: inequigranular & Qpi & 0 & 0 & 4 & 1 & 4 & 8 & 0 & 0 & 2 & 1 & 1 & 1 \\
\hline Qp: foliated & Qpf & 10 & 17 & 11 & 7 & 5 & 17 & 13 & 12 & 19 & 19 & 7 & 6 \\
\hline Qp: coarse & Qpc & 4 & 5 & 5 & 13 & 6 & 14 & 6 & 15 & 21 & 14 & 20 & 8 \\
\hline Total polycrystalline quartz & Qp & 15 & 22 & 20 & 21 & 15 & 39 & 19 & 27 & 41 & 35 & 28 & 15 \\
\hline Total quartz & Q & 43 & 52 & 55 & 46 & 69 & 67 & 54 & 67 & 69 & 70 & 59 & 69 \\
\hline Orthoclase & Ko & 0 & 1 & 0 & 1 & 0 & 2 & 0 & 1 & 1 & 0 & 0 & 0 \\
\hline Microcline & $\mathrm{Km}$ & 1 & 0 & 1 & 0 & 0 & 0 & 0 & 1 & 0 & 0 & 0 & 0 \\
\hline Plagioclase-twinned & $\mathrm{P}$ & 0 & 2 & 1 & 1 & 2 & 0 & 1 & 3 & 1 & 0 & 2 & 1 \\
\hline Total feldspar & $\mathrm{F}$ & 1 & 3 & 3 & 2 & 2 & 2 & 1 & 4 & 2 & 1 & 2 & 1 \\
\hline Siltstone & Lslst & 2 & 0 & 1 & 3 & 0 & 1 & 8 & 3 & 9 & 4 & 7 & 1 \\
\hline Sandstone & Lsst & 3 & 2 & 2 & 5 & 1 & 2 & 10 & 3 & 8 & 4 & 4 & 1 \\
\hline Shale & Lsh & 5 & 1 & 0 & 0 & 0 & 1 & 12 & 2 & 4 & 1 & 1 & 3 \\
\hline Carbonate (detrital) & $\mathrm{Lc}$ & 13 & 15 & 8 & 8 & 5 & 3 & 5 & 4 & 3 & 5 & 5 & 6 \\
\hline Total Sedimentary lithic & Ls & 23 & 17 & 12 & 16 & 6 & 7 & 35 & 12 & 23 & 14 & 17 & 11 \\
\hline Unfoliated metaclast & Lmc & 0 & 4 & 2 & 7 & 6 & 3 & 0 & 2 & 0 & 1 & 0 & 0 \\
\hline Q-M-phyllite & Lphy & 8 & 7 & 5 & 4 & 4 & 4 & 0 & 2 & 1 & 2 & 5 & 1 \\
\hline Q-M-schist & Lsc & 14 & 1 & 7 & 7 & 1 & 6 & 1 & 3 & 1 & 1 & 5 & 0 \\
\hline Amphoblite & Lamp & 1 & 2 & 0 & 0 & 0 & 0 & 0 & 1 & 0 & 0 & 0 & 0 \\
\hline Probable metamorphic lithic & Lpmr & 0 & 3 & 5 & 6 & 3 & 2 & 1 & 2 & 0 & 2 & 3 & 4 \\
\hline Total metamorphic lithic & $\mathrm{Lm}$ & 24 & 17 & 19 & 24 & 14 & 16 & 1 & 9 & 2 & 6 & 12 & 7 \\
\hline Lithics & $\mathrm{L}$ & 47 & 34 & 31 & 40 & 20 & 24 & 36 & 21 & 25 & 20 & 29 & 18 \\
\hline Total lithics & $\mathrm{Lt}$ & 61 & 56 & 50 & 62 & 36 & 62 & 55 & 48 & 66 & 55 & 57 & 33 \\
\hline Biotite & $\mathrm{Mb}$ & 2 & 3 & 3 & 3 & 2 & 2 & 5 & 3 & 2 & 1 & 3 & 2 \\
\hline Muscovite & $\mathrm{Mm}$ & 1 & 1 & 2 & 1 & 2 & 2 & 1 & 0 & 1 & 1 & 2 & 2 \\
\hline Total mica & $\mathrm{M}$ & 3 & 4 & 5 & 4 & 4 & 4 & 5 & 3 & 3 & 2 & 5 & 4 \\
\hline Heavies & $\mathrm{D}$ & 5 & 3 & 4 & 7 & 4 & 3 & 3 & 3 & 3 & 5 & 3 & 7 \\
\hline Indeterminant grains & I & 0 & 4 & 3 & 1 & 1 & 0 & 1 & 1 & 0 & 0 & 2 & 0 \\
\hline \multirow[t]{3}{*}{ Recalculated \%QFL } & $\mathrm{Q} \% \mathrm{QFL}$ & 47 & 59 & 62 & 52 & 76 & 72 & 60 & 72 & 72 & 77 & 65 & 78 \\
\hline & $\mathrm{F} \% \mathrm{QFL}$ & 2 & 3 & 3 & 2 & 2 & 2 & 1 & 5 & 2 & 1 & 2 & 2 \\
\hline & $\mathrm{L} \% \mathrm{QFL}$ & 51 & 38 & 35 & 46 & 22 & 26 & 40 & 23 & 26 & 22 & 33 & 20 \\
\hline \multirow[t]{3}{*}{ Recalculated $\%$ QmFLt } & Qm \%QmFLt & 31 & 34 & 39 & 28 & 59 & 30 & 39 & 44 & 29 & 39 & 34 & 61 \\
\hline & $\mathrm{F} \% \mathrm{QmFLt}$ & 2 & 3 & 3 & 2 & 2 & 2 & 1 & 5 & 2 & 1 & 2 & 2 \\
\hline & Lt \%QmFLt & 68 & 63 & 57 & 70 & 39 & 68 & 60 & 52 & 70 & 60 & 64 & 37 \\
\hline \multirow[t]{2}{*}{ Recalculated \%LsLmLv } & Ls \%LsLmLv & 49 & 51 & 39 & 40 & 31 & 31 & 96 & 56 & 94 & 71 & 59 & 61 \\
\hline & Lm \% LsLmLv & 51 & 49 & 61 & 60 & 69 & 69 & 4 & 44 & 6 & 29 & 41 & 39 \\
\hline
\end{tabular}

$\mathrm{Qm}=\mathrm{Qmu}+\mathrm{Qmnu} ; \mathrm{Qp}=\mathrm{Qpe}+\mathrm{Qpi}+\mathrm{Qpf}+\mathrm{Qpc} ; \mathrm{F}=\mathrm{Ko}+\mathrm{Km}+\mathrm{P} ; \mathrm{Ls}=\mathrm{Lslst}+\mathrm{Lsst}+\mathrm{Lsh}+\mathrm{Lc} ;$

$\mathrm{Lm}=\mathrm{Lmc}+\mathrm{Lphy}+\mathrm{Lsc}+\mathrm{Lamp}+\mathrm{Lpmr} ; \mathrm{L}=\mathrm{Ls}+\mathrm{Lm} ; \mathrm{Lt}=\mathrm{L}+\mathrm{Qp} ; \mathrm{M}=\mathrm{Mb}+\mathrm{Mm}$

2. As the river emerges from the Sub-Himalaya into the Dun Valley the amount of feldspar becomes quite low (1-4\%) in sands most probably due to dilution of feldspar by weathering and rapid breakdown in headwaters. No further significant variation of feldspar exists along the low-gradient stretch of the Rapti River, however maturity of sand improves downstream significantly.

3. The Rapti River sands plot on recycled orogeny field of QFL diagram, and transitional recycled field 


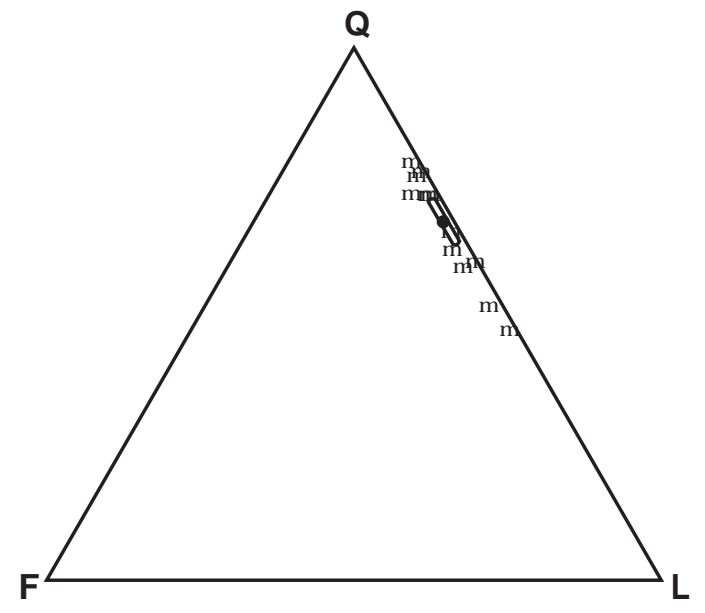

(a)

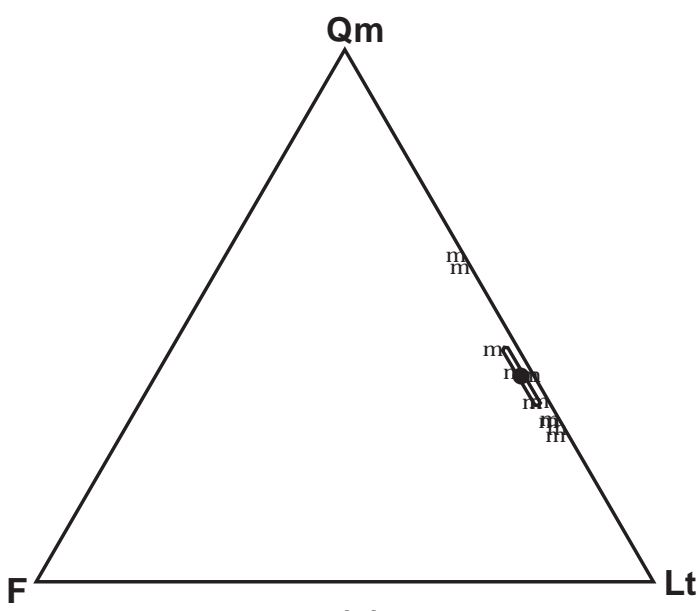

(b)

Fig. 6 Ternary diagrams showing modal composition of the Rapti Rriver sand: (a) QFL triangul diagram and (b) QmFLt triangle diagram. Solid circles and polygons indicate means and one standard deviations. Open circles represent plots of samples; $(Q=$ total quartz; F = total feldspar $; \mathrm{L}=$ lithic fragments; $\mathrm{Qm}=$ monocrystalline quartz; $\mathrm{Lt}=$ total lithic fragments $(\mathrm{L})+$ polycrystalline quartz $(\mathrm{Qp}))$

of QmFLt diagram. These sands are poorer in feldspar compared to the modern and ancient sands or sandstones from the other regions having similar tectonic setting.

4. Despite of compositional variation of sands and sandstones from different climates and environments, all of them plot on recycled provenance fields, and do not show major difference in provenance. Although these sand and sandstones show similar tectonic setting, the difference in major mineralogical components in them happens depending perhaps on relief and climate. The Rapti River sand thus provides an example of recycled orogeny provenance of a long low-gradient stream in humid

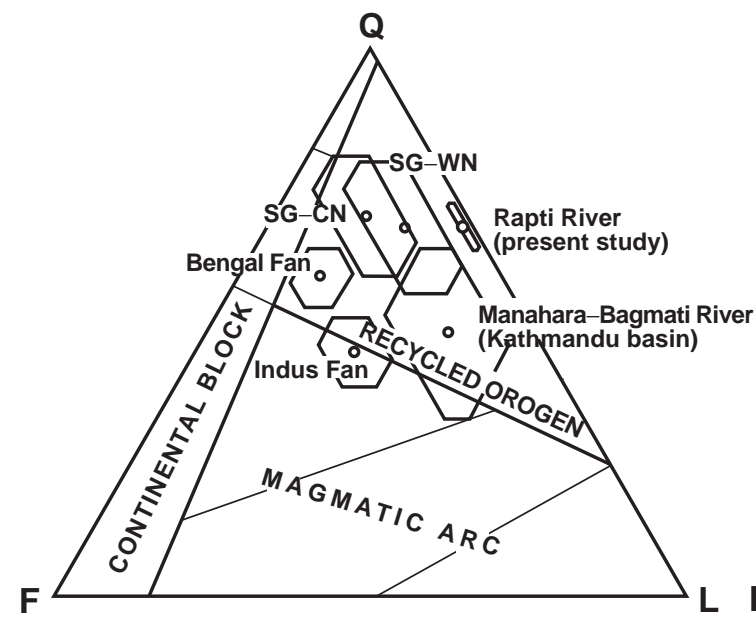

(a)

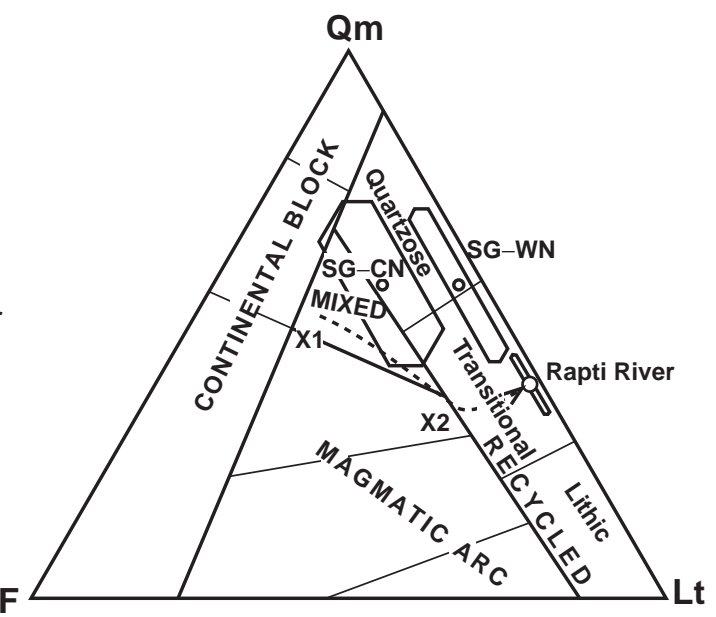

(b)

Fig. 7 Ternary diagrams: (a) QFL triangle and (b) QmFLt triangle showing provenance of sands from the Rapti River, and comparison with sand and sandstones from other areas. Compositional field names and boundaries in diagrams are from Dickinson et al. (1983). Means and standard deviations are represented by circles and polygons, respectively. See Fig. 6 and Table 2 for grain description. Data include: sands from Manahara-Bagmati River of the Kathmandu Basin (Tamrakar and Gurmaita 2001); remnant-ocean sand of the modern Bengal and Indus Fans (from Ingersoll and Suczek 1979, and Suczek and Ingersoll 1985); foreland sandstone of the middle Miocene-Pliocene Siwalik Group of Central Nepal (SG-CN) (Tamrakar, 2004) and Siwalik Group of Western Nepal (SGMWN) (Tamarkar 1993); X1 and X2 = Rapti River sands (data from DeCelles et al. 1998); dotted line represents compositional shift from quartzo-feldspathic to quartzo-lithic sands from headwaters (X1) to middle and distal portion of the Rapti River 
sub-tropical basin of the Sub-Himalaya.

\section{ACKNOWLEDGEMENTS}

Authors are thankful to the Central Department of Geology, Tribhuvan University for providing laboratory facility.

\section{REFERENCES}

Arribas, J., Critelli, S, LePera, E., Tortosa, A., 2000. Composition of modern stream sand derived from a mixture of sedimentary and metamorphic rocks (Henares River, Central Spain). Sed. Geology, v. 133, pp. 27-48.

Breyer, J.A., and Bart, H.A., 1978. The composition of fluvial sands in a temperate semiarid region. Jour. Sed. Petrology, v. 48, no. 4, pp. 1311-1320.

Cavazza, W., Zuffa, G.G., Camporesi, C., Ferretti, C., 1993. Sedimentary recycling in the temperate climate drainage basin (Senio River, north central Italy); Composition of source rock, soil profile, and fluvial deposits. In: M. J., Johnson, A., Basu (Eds.), Processes controlling the composition of clastic sediments. Geol. Soc. of America, Special Paper, v. 284, pp. 247-260.

Cox, R. and Lowe, D.R., 1995. A conceptual review of regional-scale controls on the composition of clastic sediment and the co-evolution of continental blocks and their sedimentary cover. Jour. Sed. Research, v. A65, no. 1, pp. 1-12.

DeCelles, P.G., Gehrels, G.E., Quade, J., Ojha, T.P., Kapp, P.A. and Upreti, B.N., 1998, Neogene foreland basin deposits, erosional unroofing, and the kinematic history of the Himalayan fold-thrust belt, western Nepal. Bull. Geol. Soc. America, v. 110, no. 1, pp. 2-21.

DHM, 1998. Hydrological records of Nepal, stream flow summary, Department of hydrology and meteorology (DHM), Ministry of science and technology, Kathmandu, Nepal.

Dickinson, W.R., Beard, L. S., Brakenridge, G.R., Erjavec, J.L., Ferguson, R.C., Inman, K.F., Knepp, R.A., Lindberg, F.A. and Ryberg, P.T., 1983. Provenance of North American Phanerozoic sandtones in relation to tectonic setting. Geol. Soc. America Bull., v. 94, pp. 222-235.

Dickinson, W.R., Lawton, T.F., and Inman, K.F., 1986. Sandstone detrital modes, central Utah Foreland region: Stratigraphic record of Cretaceous-Paleogene tectonic evolution. Jour. Sed. Petrology, v. 56 (2), pp. 276-293.

DMG, 1984. Geological map of central Nepal. Department of Mines and Geology, Kathmandu, Nepal. Hayes, J.R., 1962. Quartz and feldspar content in South
Platte and Missouri River sands. Jour. Sed. Petrology, v. 32, pp. 793-800.

Ingersoll, R.V., and Suczek, C.A., 1979. Petrology and provenance of Neogene sand from Nicobar and Bengal Fans, DSDP sites, 211 and 218. Jour. Sed. Petrology, v. 49 (4), pp. 1217-1228.

Johnsson, M.J., 1990. Tectonic versus chemical-weathering controls on the composition of fluvial sands in tropical environments. Sedimentology, v. 37, pp. 713-116.

Johnsson, M.J., 1993. The system controlling the composition of clastic sediments. In: Johnsson, M.J., Basu, A. (Eds), Processes controlling the composition of clastic sediments, Geol. Soc. of America. Special paper, v. 284, pp. 1-19.

Kimura, K., 1994. Formation and Deformation of River Terraces in the Hetauda Dun, Central Nepal; A Contribution to the Study of Post Siwalikan Tectonics. The Science Report of the Tohoku University, 7th Series (Geography), 44, 2, pp. 151-181.

Mann, W.R. and Cavaroc, V.V., 1973. Composition of sand released from three source areas under, humid low relief weathering in the North Carolina Piedmont. Jour. Sed. Petrlogy, v. 43, pp. 870-881.

Pettijohn, F.J., 1984. Sedimentary Rocks. CBS Publishers and Distributors, Delhi, III eds., 628p.

Stöcklin, J. and Bhattarai, K.D., 1982. Photogeological map of part of central Nepal. Tehran Naqshah Offset Press, Iran.

Suczek, C.A. and Ingersoll, R.V., 1985. Petrology and provenance of Cenozoic sand from the Indus Cone and the Arabian Basin, DSDP Sites 221, 222, and 224. Jour. Sed. Petrology, v. 55, no. 3, pp. 340-346.

Tamrakar, N.K., 1993. Petrography of the Siwalik rocks of the Bardanda-Surai Naka area, West Nepal. M. Sc. Dissertation submitted to the Central Department of Geology, Tribhuvan University, Kathmandu, Nepal, 140p.

Tamrakar, N.K., 2004. Petrographic properties and their relationship with engineering properties of the Siwalik sandstones, central Nepal. Ph. D. dissertation submitted to the Central Department of Geology, Tribhuvan University, Kathmandu, Nepal, 215p.

Tamrakar, N.K. and Gurmaita, H.N., 2001. Textural and compositional variation of sand along the Manahara-Bagmati river basin, Kathmandu Valley. Jour. Nepal Geol. Soc., v. 23, pp. 27-36.

Tamrakar, N.K., Yokota, S., Shrestha, S.D., 2002. Physical and geomechanical properties of the Siwalik sandstones, Amlekhganj-Suparitar area, central Nepal Himalaya. Jour. Nepal Geol. Soc., v. 26, pp. 59-71. 